\title{
The town that disappeared - Dhanushkodi - a Case Study
}

\author{
Ar. Rajshekhar Rao ${ }^{a}$ \\ Associate Professor, M.S.Ramaiah Institute of Technology, Bangalore, India
}

\begin{abstract}
Danushkodi was a small town at the southern tip of the Rameswaram island, at the eastern coast of theTamil Nadu state of India. Danushkodi island is about $29 \mathrm{~km}$ West of Talaimannar in Sri Lanka. It was in December 1964 a cyclone wiped out the town of Dhanushkodi, the sea also took away 2000 lives and crippling power supply and communications. Before the 1964 cyclone, Dhanushkodi was a flourishing tourist and pilgrimage town. Since Sri Lanka is just $31 \mathrm{~km}$ away, there were many ferry services between Dhanushkodi and Talaimannar of Srilanka, transporting travelers and goods across the sea. There were hotels, textile shops and dharmashalas catering to these pilgrims and travelers. From temples to churches, houses, dharmashalas, roads and railway station, all were destroyed leaving no signs of life. Once upon a time Dhanushkodi was full of flourishing tourist but now it has become Ghost town. However the remains of this town still exist recalling the old memories of the town attracting many tourists, but the remaining structures are currently threatened by erosion and negligence in restoration.

The paper reviews the history of the town that disappeared and recalls the memory of the town and also discuss about potential of developing the remains of Dhanushkodi Island as tourist place.
\end{abstract}

Key Words: Erosion, Island, Pilgrimage town, Restoration, Tourist

\subsection{History of Dhanushkodi}

\section{Introduction:}

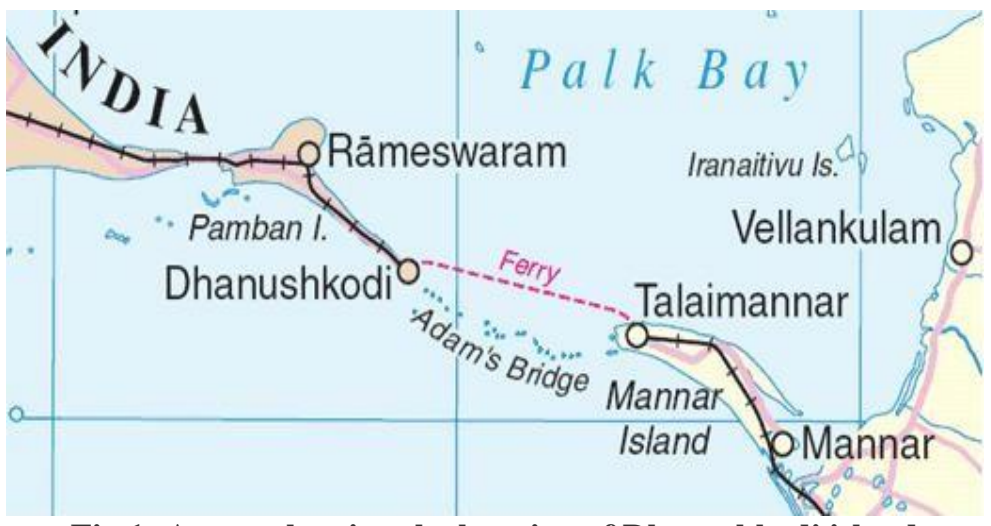

Fig.1: A map showing the location of Dhanushkodi island

Hindu scriptures says that at the request of Vibeeshana, brother of Ravan and ally of Ram, Rama broke the Sethu with one end of his bow and hence the name Dhanushkodi, Dhanush meaning Bow and Kodi meaning end. It is also said that Rama marked this spot for Setu with one end of his famous bow. Bath in holy Sethu at the junction of the two seas normally precedes the pilgrimage to Rameswaram. A series of rocks and islets found in a line are shown as remnants of the ancient Setu also called as Rama's Bridge

Dhanushkodi has the only land border between India and Sri Lanka (Fig.1) which is one of the smallest in the world-just 50 yards in length on a shoal in Palk Strait. Before the 1964 cyclone, Dhanushkodi was a flourishing tourist and pilgrimage town. Dhanushkodi in those days had a railway station, a small railway hospital, a higher secondary school, a post office, customs and port offices etc

After the cyclone, a portion of the railway track at Dhanushkodi was also swept away. The Southern part of Dhanushkodi surrounded by the buildings including temples was submerged in the sea. In the year 1965, the Government of Madras declared the town as unfit for living. At present a small group of fisher folk only reside in Dhanushkodi. Haunting yet appealing, deserted but still full of life, eerie but fascinating Dhanushkodi attracting many tourists. Breathtaking beauty, a population of less than 500, the nearest telephone about $20 \mathrm{~km}$ away, and the feeling of being in a place which was once alive, now reduced to rubble, makes it a place truly less travelled. 


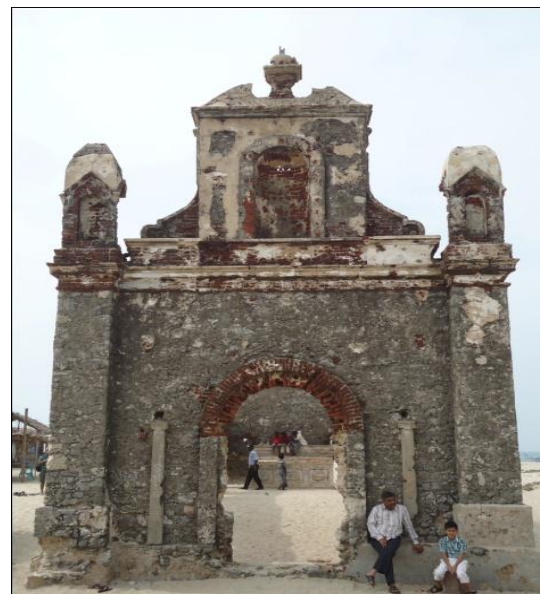

Fig. 2: Destroyed church Dhanushkodi

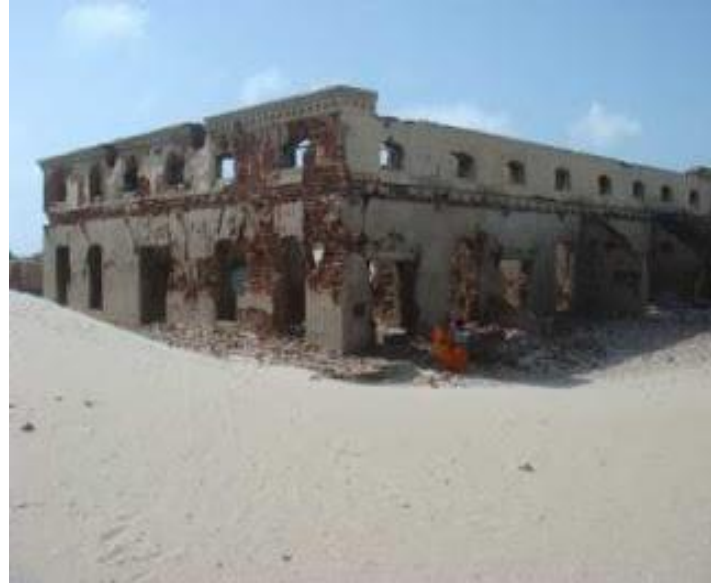

Fig 3: Old Railway station

At present roofless shattered building a church.(Fig.2) Inside, a pedestal, which could have been the altar, stands intact.A ruined railway station (Fig.3) and a temple lie among the debris. But the shells of the structures sit peacefully in dunes of white sand against a deceivingly calm and sparkling blue sea. Railway office made up of stone structure standing with other buildings tells the story of the town. Overhead water tank (Fig.4) supporting structure made with stone masonry with stone lintels in between with arch was fascinating, stands next to railway station. The town also had big post office (Fig.5) built with stone masonry and brick arch openings.

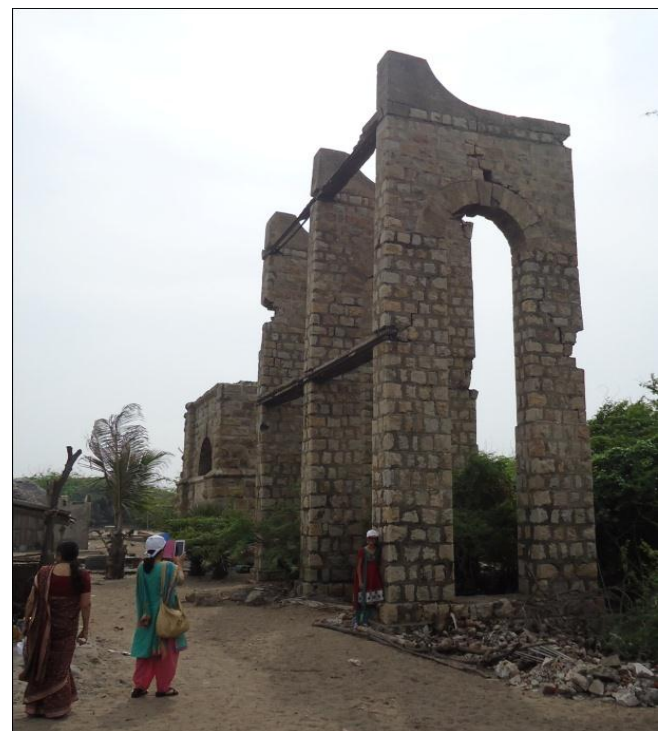

Fig.4: Remains Overhead water tank structure

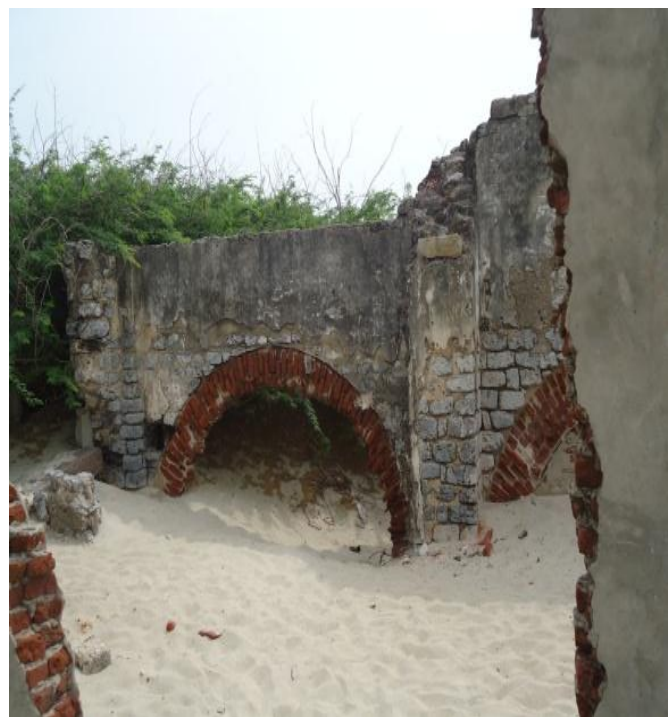

Fig.5: Destroyed post office

A scientific study conducted by the Geological Survey of India indicated that the southern part of erstwhile Dhanushkodi Township facing Gulf of Mannar sank by almost by 5 meters due to vertical tectonic movement of land parallel to the coastline. As a result of this, a patch of land of about half a km in width stretching $7 \mathrm{~km}$ along North-South direction submerged in sea along with many places of worship, residential areas, roads etc.

The Government of Madras declared the town as Ghost town and unfit for living after the storm, now a small group of fisher folk resides there. For reaching the village one has to go in a four wheel drive or in a fish cart.

\subsection{Aim of the study:}

To understand the glory of remains of Dhanushkodi town

To understand the possibilities of revival of the remains of Dhanushkodi town 


\subsection{Methodology:}

A Case study method is used as research method; used techniques such as observation, interviews etc.,are conducted to discover the remains of Dhanushkodi town.The secondary data collected included the information from the offices. The methodologies that have been used primarily include primary, secondary and public opinion survey along with personal observations, site visits which were conducted in order to get data related to various aspects and understand the existing conditions. Studies were basically done at two levels, the site level and at building level. The key parameters include Assessment of existing site condition, extent of site, extent of remains of building, building design, and Building materials used and services.

\section{Architecture and infrastructure}

Dhanushkodi village town looks like very well planned town. The area covered by the town range from 40 to 45 sq.miles with peak population at around 5,000.The sheer size of the town, and its provision of public buildings and facilities, suggests a high level of social organization. The public buildings include hospital, school, church, Temple, Dharmashala, a place to stay for tourists \& all built in British style.

All Public buildings are planned well and clustered houses placed little away but easily accessible. Most of the public buildings were built out of stone masonry walls with lime mortar, Houses are built out of brick wall masonry plastered with cement plaster.

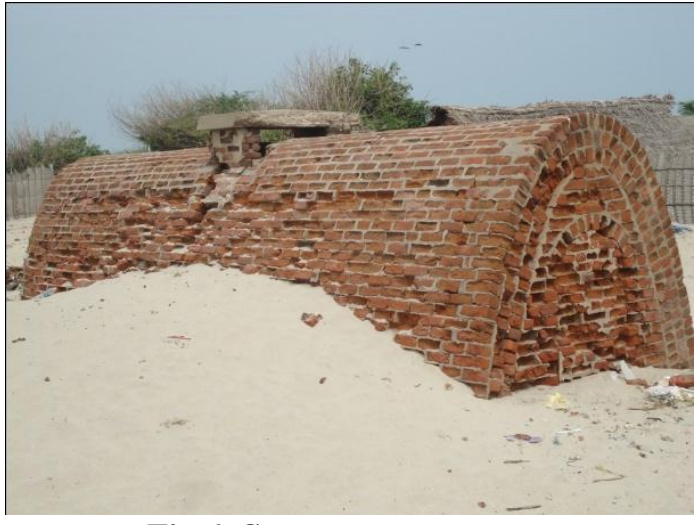

Fig 6: Storage space

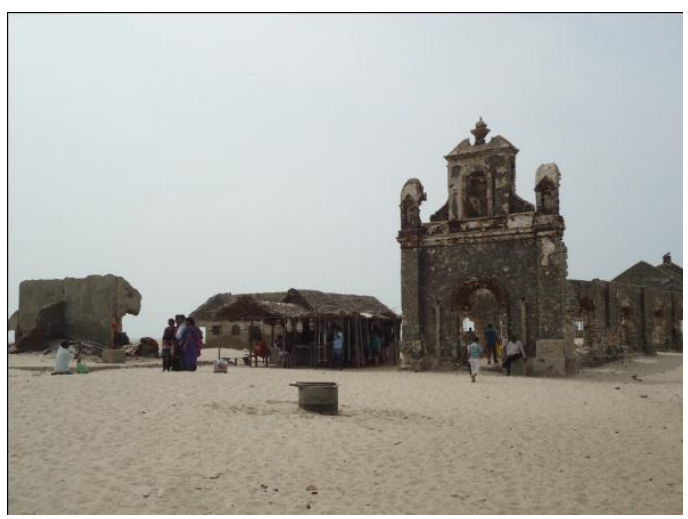

Fig 7: Ruined church with office buildings

The town had a market place, individual households or group of house households obtained their water from smaller wells. Most of the houses are ground floor structure and some of them had two stories also. All the public building had gable end wooden roof with Mangalore tiled roof. Most of the house with brick wall and thatch roof structure. Brick arch openings were used for the hospital \& post office building. Brick vault structures were used for storage purpose (Fig.6) with top ventilation. Due to cyclone the tidal waves had swallowed the town and its residents. No building was intact.

\section{Public Buildings:}

There were remains of a church, railway station, School, (Fig.7) all built in the British style. They have stone walls and that's precisely why they are still there when all the other residential buildings made by local population were washed away. The railway station was built in stone wall structure. Church was built by stone masonry with a rocky altar. The remaining portions of the walls have disintegrated in the saline water and air. All the building built here was load bearing structure either made of stone or brick masonry. All the facilities were provided in this village town like post office and hospital buildings for the local people and for the tourist. Remains of Dharmashalas shows it might be built for the tourist and pilgrims stay in Dhanushkodi town.

\section{Present Scenario:}

What is left today are the white sands, salt-eaten ruins and a handful of fisher families who have made the barren land their home with thatch walls \& roof (Fig.8). The fishermen's houses are built with thatch wall and roofs without electricity, people are using solar panels, which is fixed on the thatch roof for electricity. All the houses are depending on small wells (Fig.9) for sweet drinking water. It is surprise to see sweet water wells even though sea is just 300mts away, due to the sea Aquifers. The children of the fishermen approach the pilgrims, who come to Dhanushkodi to perform last rites to their dear ones, to buy seashells. Time and again there is talk of reviving the town but little effort has been made, for such was the scale of devastation. Casuarina groves have sprung around the twisted train tracks. 


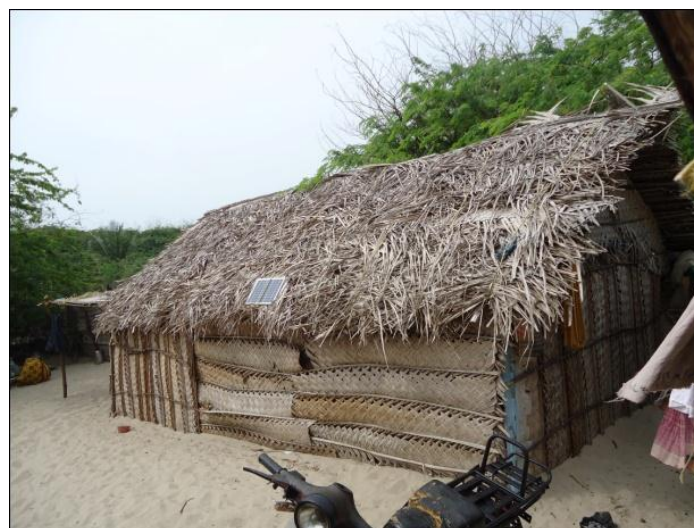

Fig.8: The Thatched huts of the fisher folk

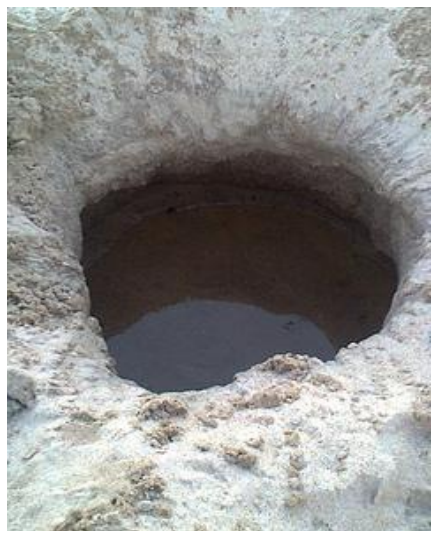

Fig. 9: Small wells provide sweet water

\section{Findings}

Danushkodi now attracts thousands of visitors in spite of the lack of proper transportation. At present there are several fisher folk who reside in huts. The Government of India declared Danushkodi as unsafe for habitation and so no attempts were made to re construct the site or restore its connectivity to the main land. However, Hindu pilgrims and curious travelers have continued to visit the ghost town. For centuries Hindu devotees embarking on a religious journey to nearby Rameshwaram have been stopping at Danushkodi to see the remains of the town.

Danushkodi has much to offer beyond the religious sentiment. Though unfit for human habitation, Danushkodi has been a favorite haunt for a variety of sea birds that migrate here for a season. The vast stretches of sea shore that surround this ruined town also unfold the diversity of marine wealth here. Corals, sea grass, sea cucumbers and variety of life forms peculiar to the ocean can be spotted along the coast. This makes Danushkodi a haven for researchers and naturalists to further their interests.

\section{Conclusion:}

Dhanushkodi which was once an important hub in Rameswaram Island prior to 1964 cyclone is now a neglected spot. Instead of paying homage to the victims, the Centre and State must bring in more infrastructures and revive Dhanushkodi.

Danushkodi will never be rebuilt. But we can definitely restore it, the few survivors who managed to defy nature's fury live to look back at an eventful past and mourn the destruction of their home town. The ordinary buildings which once housed simple citizens and local establishments are now a relic. Even if these leftovers bury in time, memories of loved ones who lived and worked in this quaint city will continue to live in posterity.

Though this site is an important one for pilgrims, many fail to visit this site due to lack of easy access. Rail connectivity and ferry service must be restored to increase tourist flow. As it is the haunt of migratory birds, this could also be used to woo the tourists. Archiologist should go through the potential of remains of Dhanushkodi town and could revive so that people could recall the memory of the town, the high velocity wind in the region can be tapped to generate wind energy. If all these could become a reality then Dhanushkodi could be developed as a multipurpose hub.

\section{References}

[1] Rossi, A. (1982), Garg, Ganga Ram (1992). "Eve's Bridge". Encyclopaedia of the Hindu World. A-Aj. New Delhi: South Asia Books. p. 142.

[2] The Architecture of the City, MIT: The Institute for architecture and Urban Studies.

[3] Shah, B. (2003), "Heritage Conservation and Planning, New Development in Bhaktap ur Nepal", 6th US/ICOMOS International Symposium

[4] Clark,kate, Informed conservation: understanding historic buildings and their landscape for conservation London: English heritage, 2001

[5] Warke,P.A et al. "Condition assessment for building stone conservations a staging system approach" Building environment 38.9-10 (2003) :1113-1123.

[6] Winker.Erhard M “The decay of building stones.A literature review”APT Bulletin 9.4 (1977) :53-61

[7] Winkler Erhard M stone in Architecture properties,durability $3^{\text {rd }}$ ed. Berlin : Springer 1994 